\title{
Tatvan'da Tüketime Sunulan Tavuk Dönerlerin Mikrobiyolojik Kalitesi
}

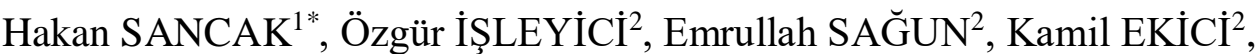 \\ Dilara BAŞAT DERELI' ${ }^{3}$, Yakup Can SANCAK ${ }^{2}$
}

\author{
${ }^{1}$ Bitlis Eren Üniversitesi, Tatvan Meslek Yüksekokulu, Gıda İșleme Bölümü, Bitlis \\ ${ }^{2}$ Van Yüzüncü Yll Üniversitesi, Veteriner Fakültesi, Besin Hijyeni ve Teknolojisi Bölümü, Zeve Kampüsü, Van \\ ${ }^{3}$ Bitlis Eren Üniversitesi, Tatvan Meslek Yüksekokulu, Kimya ve Kimyasal İşleme Teknolojileri Bölümü, Bitlis \\ (ORCID: 0000-0002-2769-1855) (ORCID: 0000-0001-6319-3880) (ORCID: 0000-0003-4555-9193) \\ (ORCID: 0000-0002-6413-4361) (ORCID: 0000-0003-1328-077X) (ORCID: 0000-0003-4490-9606)
}

\begin{abstract}
$\ddot{O} \mathbf{z}$
Bu araştırma, Bitlis'in Tatvan ilçesinde farklı lokanta ve işletmelerde pişirilmiş olarak tüketime sunulan tavuk dönerlerin mikrobiyolojik ve fiziko-kimyasal kalitesini tespit etmek amacıyla yapılmıştır. Bu amaçla 50 adet tavuk döner numunesi incelenmiştir. Numunelerin mikrobiyolojik analizleri sonucunda ortalama toplam aerob mezofilik mikroorganizma (TAMM), koliform grubu mikroorganizma, Escherichia coli, Staphylococcus aureus, koagulaz (+) S. aureus, laktobasiller, Enterobacteriaceae grubu mikroorganizma, Pseudomonas spp. ile maya-küf sayıları sirasiyla $4.86 \pm 0.94 \log _{10} \mathrm{kob} / \mathrm{g}, 2.34 \pm 1.17 \log _{10} \mathrm{kob} / \mathrm{g}, 2.84 \pm 0.85 \log _{10} \mathrm{kob} / \mathrm{g}, 4.00 \pm 1.04 \log _{10} \mathrm{kob} / \mathrm{g}, 3.79 \pm 1.23$ $\log _{10} \mathrm{kob} / \mathrm{g}, 3.70 \pm 1.41 \log _{10} \mathrm{kob} / \mathrm{g}, 2.64 \pm 1.04 \log _{10} \mathrm{kob} / \mathrm{g}, 3.19 \pm 0.63 \log _{10} \mathrm{kob} / \mathrm{g}$ ve $2.39 \pm 1.02 \log _{10} \mathrm{kob} / \mathrm{g}$ olarak belirlenmiştir. İncelenen numunelerde Salmonella spp. ve sülfit indirgeyen anaerob mikroorganizmalara rastlanmamıştır. Fiziko-kimyasal analizler sonucunda da numunelerdeki ortalama $\mathrm{pH}$ ve su aktivitesi $\left(\mathrm{a}_{\mathrm{w}}\right)$ değerleri sırasıyla $6.12 \pm 0.20$ ve $0.985 \pm 0.01$ olarak tespit edilmiştir. İncelenen numunelerin sadece Salmonella spp. yönünden standartlarda belirtilen kriterlere uygun olduğu görülmüştür. Bununla birlikte, mikrobiyolojik özellikler yönünden pişirilmiş haldeki tavuk dönerlerin bazı mikroorganizmalar yönünden hijyenik kalitesinin iyi olmadığı, ayrıca incelenen numunelerin \%8'inin E. coli ve $\% 22$ 'sinin de $S$. aureus yönünden standartlara uygun olmadığ 1 tespit edilmiştir. Sonuç olarak; üretimde kaliteli hammadde kullanıldığında, etkin ve yeterli pişirme işlemleri uygulandığında, üretim/servis sırasında hijyenik kurallara gerekli özen gösterildiğinde ve personeller hijyen konusunda yeterli bilgiye sahip olduklarında halk sağlığı açısından risk oluşturmayacak daha kaliteli ürünlerin elde edilmesi mümkün olacaktır.
\end{abstract}

Anahtar kelimeler: Tavuk döner, Isıl işlem, Mikrobiyolojik kalite, Hijyen, Tatvan

\section{Microbiological Quality of Chicken Doners Presented for Consumed in Tatvan}

\begin{abstract}
This study was carried out in order to determine the microbiological and physicochemical quality of cooked chicken doners in different restaurant and food businesses in the Tatvan district of Bitlis province in Turkey. For this purpose, 50 chicken doner samples were examined. As a result of microbiological analysis of samples, the average total aerobic mesophilic microorganism (TAMM), coliform group microorganism, Escherichia coli, Staphylococcus aureus, coagulase-positive S. aureus, lactobacilli, Enterobacteriaceae, Pseudomonas spp. and the yeast-mold numbers were detected as $4.86 \pm 0.94 \log _{10} \mathrm{kob} / \mathrm{g}, 2.34 \pm 1.17 \log _{10} \mathrm{kob} / \mathrm{g}, 2.84 \pm 0.85 \log _{10} \mathrm{kob} / \mathrm{g}$, $4.00 \pm 1.04 \log _{10} \mathrm{kob} / \mathrm{g}, 3.79 \pm 1.23 \log _{10} \mathrm{kob} / \mathrm{g}, 3.70 \pm 1.41 \log _{10} \mathrm{kob} / \mathrm{g}, 2.64 \pm 1.04 \log _{10} \mathrm{kob} / \mathrm{g}, 3.19 \pm 0.63 \log _{10} \mathrm{kob} / \mathrm{g}$ and $2.39 \pm 1.02 \log _{10} \mathrm{kob} / \mathrm{g}$, respectively. No Salmonella spp. and sulfide-reducing anaerobic microorganisms were found in the analyzed samples. As a result of physicochemical analysis, the average $\mathrm{pH}$ and water activity $\left(\mathrm{a}_{\mathrm{w}}\right)$ values in the samples were determined as $6.12 \pm 0.20$ and $0.985 \pm 0.01$, respectively. It was observed that the samples met the criteria specified in the standards only in terms of Salmonella spp. However, it was noted that cooked chicken doners are not hygienic in terms of some microorganisms, and $8 \%$ of the samples examined were not in compliance with the standards in terms of $E$. coli and $22 \%$ were not suitable in terms of $S$. aureus. In conclusion, if the quality raw material is used during production, effective and sufficient cooking processes are used, attention
\end{abstract}

\footnotetext{
*Sorumlu yazar: hsancak@beu.edu.tr

Geliş Tarihi: 26.06.2020, Kabul Tarihi: 13.07.2020
} 
is paid to hygienic rules during production/service, and personnel have sufficient knowledge about hygiene, it will be possible to obtain higher quality products that will not pose a risk for public health.

Keywords: Chicken doner, Heat treatment, Microbiological quality, Hygiene, Tatvan

\section{Giriș}

Yeterli ve dengeli beslenmede hayvansal kökenli besinlerin önemi büyük olup, bunların bir kısmını et ve et ürünleri oluşturmaktadır. Biyolojik değeri yüksek proteinler, özellikle B grubu vitaminler ve mineral maddeler bakımından zengin olan kırmızı et ve kanatlı etlerinin beslenmede önemli fonksiyonları bulunmaktadır [1-3]. İnsanların yaşam tarzları ve çalışma şartlarındaki değişimlere bağlı olarak hazır gıdalara olan talebin artmasıyla birlikte, standartlara uygun olmayan ve hijyenik şartlarda üretilmeyen gidaların tüketilmesi sonucunda da sağlık problemleri yaşanabilmektedir. Kırmızı etten ve kanatlı etlerinden üretilen dönerlerin hazır yiyecekler açısından piyasada oldukça rağbet gördüğü, özellikle tavuk dönerlerin de ekonomik açıdan dar gelirli tüketiciler tarafindan tercih edildiği gözlenmektedir.

Döner, Türk Gıda Kodeksi Et, Hazırlanmış Et Karışımları ve Et Ürünleri Tebliği [4]'nde "Büyükbaş ve küçükbaş hayvan karkas etlerinin ve/veya kıymalarının ya da kanatlı hayvan karkas etlerinin ve/veya kıymalarının bu Tebliğ'e uygun olacak şekilde biri veya birkaçının karışımına, aynı ve/veya farklı tür hayvanların yağları, lezzzet vericiler ile diğer gıda bileşenlerinden biri veya birkaçı ilave edilerek hazırlanan ve döner şişine dizilerek silindir formu verilmiş pişirilmeye hazır kırmızı veya kanatlı et karışımının yatay veya dikey olarak döndürülerek pişirilmesiyle elde edilen et ürününü ifade eder" şeklinde tanımlanmıştır. Aynı tebliğde dönerlerin piyasaya sunuş şekillerinin çiğ kırmızı etten üretilenler için 'yaprak döner', 'kıyma döner' ve 'karışık döner' olmak üzere üç çeşide ayrıldı̆̆ kanatlı etinden üretilenler için ise 'yaprak kanatlı eti döneri' ve 'karışık kanatlı eti döneri' olmak üzere ikiye ayrıldığı belirtilmiştir.

Türkiye'de yaygın olarak tüketilen ve fast-food kültürünün önemli yiyecekleri arasında yer alan döner, bazı ülkelerde dona kebab, gyro, gyros, yeeros, souvlaki, chawarma ve shawarma gibi farklı isimlerle bilinmektedir. TS 11658 Döner Yapım Kurallarına göre [5] döner yapılacak tavuk ve hindi gövde etleri, ekstra birinci ve ikinci sınıf olacak şekilde iri gövde etlerinden seçilmelidir. Kanatlı eti dönerinin üretiminde kemik, tüy, dipcik, damar, yemek borusu, nefes borusu ve barsak parçalarından arındırılan iri gövdeli tavuk ve hindi etleri derileriyle beraber parçalanır ve etler yaprak veya kıyma haline getirilerek kullanılır [5, 6]. Genellikle yaprak şeklinde kesilen veya kıyma haline getirilen döner yapılacak ete tuz-baharat karışımı serpilir ve iki saat bekletilen yapraklar marinasyon harcı ile iyice karıştırılır [3]. Standart döner yapımına [5] göre de parçalanan etlere tuz ve baharat karışımları eklendikten sonra yemeklik zeytinyağı, süt, yoğurt, yumurta, soğan, domates veya salça, limon suyu, sirke, üzüm şırası ve beyaz şeker gibi lezzet verici maddeler katılarak terbiye edilir. Dinlendirilmiş bu karışım temelin oluşturulması amacıyla dik şekildeki döner hazırlama aparatının en altına sağlam yapraklar yerleştirilecek şekilde üst üste dizilir ve bastırarak sıkıştırılır. Sarkan fazlalıklar tıraşlanarak alınıp ters yumurta şekli verilir ve pişirilmeye hazır hale getirilir. İsteğe bağlı olarak döner katları arasına yeşilbiber ve dilimlenmiş domates bırakılabilir. Döner genellikle gazla ve elektrikle çalışan ocaklarda, odun ateşi veya robax camlı ısıtıcı önünde yavaşça çevrilerek pişirilir ve sonrasında ince/küçük parçalı dilimler halinde kesilerek servis edilir. Dönerin kömür veya zehirli gazlarla temasını önleyen robax camlı ocakların kullanılması en sağlıklı yöntemdir [3].

Uygun 1sı derecelerinde ve yeterli sürelerde pişirilen dönerlerin yüzey kısımları mikrobiyolojik açıdan güvenilir olarak değerlendirilebilir [7]. Ancak yoğunluğa bağlı olarak genellikle öğlen saatlerinde dönerlerin yeterli pişirme süresine riayet edilmeden servis edilmesi ve talebi hızlı bir şekilde karşılayabilmek için dönerin kalınca kesilerek ısının temas etmediği iç kısımlarının da alınması mikrobiyolojik riskleri arttırmaktadır. Nitekim Todd ve ark. [8], dönerin iç kısımlarına kadar yeterli sıcaklık ulaşmadan kesilen ve hızlı servisten dolayı yetersiz pişirilen dönerlerdeki patojen mikroorganizmaların inaktivasyonunda başarıya ulaşmanın mümkün olmayacağını bildirmişlerdir.

Isıl işlem görmüş ürünlerin uygun olmayan sağlıksız şartlarda uzun süre bekletilmesi, canlılığını kaybetmemiş veya çeşitli kontaminasyonlara bağlı olarak gelişen mikroorganizmaların üründe hızla çoğalması açısından tehlikelidir [9]. Dönerlerin bazen kesilmiş halde bekletilmesi veya müşterilere paket servis yapılması sırasında belirli bir zamanın geçmesi de, tüketicilerin sağlığı açısından potansiyel 
riskler oluşturabilmektedir. Küpeli Gençer ve Kaya [10] ile Cebirbay [11], gün içinde tüketilmeyen dönerlerin ertesi gün tekrar müşteriye sunulma çabalarının ilgili ürünlerin mikrobiyolojik kalitesini sakıncalı hale getirdiğini bildirmişlerdir. Kırmızı et ve kanatlı etinden üretilen dönerlerin satış noktalarındaki raf ömrünün, pişirme işleminin başlamasından itibaren en fazla 12 saat olması gerektiği ifade edilmektedir [4].

Et ve et ürünlerinin patojen mikroorganizmalarla kontamine olma riski diğer gıdalara göre daha fazladır. Bunun en büyük nedenleri üretimde kullanılan hammaddelerin kalitesinin düşük olması veya hijyenik olmaması, üretimin yapıldığı gıda işletmelerindeki olumsuz sanitasyon koşulları, çapraz kontaminasyonların oluşması ve ürünlerin satış için çoğu zaman uzun süre bekletilmeleridir. Bunların yanında gıda üretiminde çalışan personel ile işletmede kullanılan sulardan ve çevreden de bulaşma olabilmektedir [12]. Nitekim Tatvan ilçesine yakın olan yerlerde daha önce yapılan araştırmalarda [1318] birçok kırmızı et ve kanatlı ürünlerinin mikrobiyolojik kalitesinin çok iyi olmadığı, bunun da bölgedeki gıda işletmelerinde hijyen ve sanitasyon kurallarına hassasiyet gösterilmemesi ve çalışanların hijyen bilincinden yoksun olmaları gibi sebeplere bağlı olabileceği ifade edilmiştir. Bazı bölgelerde yapılan çalışmalarda da $[10,19-26]$ çeşitli dönerlerin mikrobiyolojik kalitelerinin çok iyi olmadığ bildirilmiştir.

Patojenlerle kontaminasyon riski oldukça fazla olan et ve et ürünlerinin hijyenik şartlarda üretimleri sağlanmazsa, bu ürünlerin tüketilmesi sonucunda önemli sağlık problemleri hatta ölümler meydana gelebilir. Bu nedenle günümüzde gıda üretimi yapan işletmelerde Tehlike Analizi ve Kritik Kontrol Noktaları (Hazard Analysis and Critical Control Points, HACCP)'nın belirlenmesi ve İyi Üretim Uygulamaları (Good Manufacturing Practices, GMP) sayesinde sağlık açısından risk oluşturmayacak ürünlerin elde edilmesinin yolları aranmaktadır. Uygulanan farklı işlemler sonucunda mikroorganizmaların üremesine müsait gıdalardan olan tavuk etinden yapılan dönerlerin, tüketicilere ulaşıncaya kadar geçen sürelerde kontaminasyon kaynaklarından etkilenip etkilenmedikleri ile ilgili araştırmaların yapılması halk sağlığı ve alınabilecek tedbirlerin belirlenmesi açısından önemlidir. $\mathrm{Bu}$ çalışma Bitlis' in Tatvan ilçesindeki lokanta ve işletmelerden müşteri yoğunluğunun fazla olduğu öğlen saatlerinde pişirilmiş olarak alınan tavuk dönerlerin mikrobiyolojik ve fiziko-kimyasal özelliklerinin belirlenmesi amacıyla yapılmıştır.

\section{Materyal ve Metot}

\subsection{Numunelerin alınması}

$\mathrm{Bu}$ araştırmada, Bitlis'in Tatvan ilçesindeki farklı lokanta ve işletmelerde pişirilmiş olarak tüketime sunulan toplam 50 adet tavuk döner numunesi materyal olarak kullanılmıştır. Tüketimin en yoğun olduğu öğlen saatlerinde aseptik şartlarda steril kaplara alınan yaklaşık $200 \mathrm{~g}$ civarındaki numuneler soğutucu kaplarda $\left(+4^{\circ} \mathrm{C}\right)$ laboratuvara getirilmiş ve en kısa sürede analizler yapılmıştır [27].

\subsection{Numunelerin mikrobiyolojik ve fiziko-kimyasal analizlere hazırlanması}

Mikrobiyolojik analizler için; laboratuvara getirilen numuneler aseptik şartlarda steril bistüri ve bıçaklarla çok küçük parçalara ayrılmış, steril stomacher torbalarında $10 \mathrm{~g}$ numune ve $90 \mathrm{ml}$ steril peptonlu su olacak şekilde homojenize edilmiştir. Daha sonra, 9'ar ml steril peptonlu su bulunan tüplerde $10^{-8}$ e kadar hazırlanan dilüsyonlardan ekimler yapılmıştır. Homojen hale getirilen numunelerden $25^{\prime}$ er g daha alınarak Salmonella spp. analizleri için ön zenginleştirme işlemleri gerçekleştirilmiş ve ekimler yapılmıştır [27]. Parçalanan numunelerden kalan kısımlar da fizikokimyasal analizler için kullanılmıştır.

\subsection{Toplam aerob mezofilik mikroorganizmaların belirlenmesi}

Plate Count Agar (Oxoid, CM0463)'a dökme plak yöntemiyle ekim yapılmış ve petriler $32 \pm 1^{\circ} \mathrm{C}$ 'de 48 saat aerob olarak inkube edildikten sonra üreyen koloniler sayılmıştır [28]. 


\subsection{Koliform grubu mikroorganizmaların belirlenmesi}

Violet Red Bile Agar (Oxoid, CM0107)'a dökme plak yöntemi ile ekim yapılmış ve petriler $37^{\circ} \mathrm{C}$ 'de 24 saat aerob olarak inkube edildikten sonra üreyen 1-2 mm çapındaki koyu kırmızı renkte ve presipitasyon oluşturan koloniler sayılmıştır [29].

\subsection{Escherichia coli'nin belirlenmesi}

Tryptone Bile X-Glucuronide Medium (TBX) (Oxoid, CM0945)'a yayma plak yöntemi ile ekim yapılmış ve petriler $44^{\circ} \mathrm{C}$ 'de $18-24$ saat aerob olarak inkube edildikten sonra üreyen mavi-yeşil renkli koloniler sayılmıştır [29, 30].

\subsection{Staphylococcus aureus ve koagulaz (+) S. aureus'un belirlenmesi}

Egg Yolk Tellurit Emulsion (Oxoid SR0054) ilave edilerek hazırlanan Baird-Parker Agar (Oxoid CM0275)'a yayma plak yöntemiyle ekim yapılmış ve petriler $37^{\circ} \mathrm{C}$ 'de $24-48$ saat aerob olarak inkube edilmiştir. İnkubasyondan sonra 1-2.5 mm çapında parlak, siyah renkli (tellürit reaksiyonu pozitif) ve etrafı halesiz koloniler (atipik) ile etrafında bir hale oluşan (yumurta sarısı veya lesitinaz reaksiyonu pozitif) koloniler (tipik) S. aureus olarak değerlendirilmiştir. Ayrıca, seçilen tipik beş koloniye koagulaz ve Staphytect Plus (Oxoid DR0850) testleri uygulanmış, bu testlerde pozitif sonuç veren koloni sayısı S. aureus sayısı ile oranlanarak koagulaz (+) S. aureus sayısı belirlenmiştir [31, 32].

\subsection{Salmonella spp.'nin belirlenmesi}

Numunelerden steril cam şişelere 25'er g tartılarak üzerine 225'er ml tamponlanmış peptonlu su (Merck 1.07228 ) ilave edilmiş ve karışım homojenize edilmiştir. Homojenizatlar ön zenginleştirme için $37^{\circ} \mathrm{C}$ ' de 24 saat inkube edilmiş, daha sonra numunelerden $0.1^{\prime} \mathrm{er} \mathrm{ml}$ alınarak içlerinde $10^{\prime}$ 'ar ml RappaportVassilliadis Broth (Oxoid CM0866) bulunan tüplere ekim yapılmış ve tüpler $43^{\circ} \mathrm{C}$ 'de $18-24$ saat inkube edilerek selektif zenginleştirme işlemi gerçekleştirilmiştir. İnkubasyon sonrası bu besiyerlerinden öze ile Brilliant-green Phenol-red Lactose Sucrose (BPLS) Agar (Merck 107237)'a ekim yapılmış, petriler $37^{\circ} \mathrm{C}$ 'de $24-48$ saat inkube edilmiş ve üreyen tipik kolonilere Gram boyama ile biyokimyasal testler (indol, motilite, oksidaz, üreaz, sülfür, laktoz, glukoz, sukroz, lizin dekarboksilaz, D-mannitol fermantasyon) uygulanmıştır. Alınan sonuçlar ve Lateks aglutinasyon testine (Microgen, Salmonella M42) verilen reaksiyonlara göre de değerlendirme yapılmıştır [33].

\subsection{Laktobasil'lerin belirlenmesi}

$\mathrm{Bu}$ amaçla de Man, Rogosa and Sharpe (MRS) Agar (Merck, 110660) kullanılmış ve dökme plak yöntemiyle ekim yapılmıştır. Eritilen MRS Agar $50^{\circ} \mathrm{C}$ 'ye soğutulmuş ve glaciyel asetik asit ile pH's1 5.4'e ayarlanarak petrilere aktarılmıştır. Katılaşan besiyerinin üzeri ikinci bir kat MRS Agar dökülerek örtülmüş ve böylece oksijenle besiyerinin irtibatı kesilmiştir. Petriler $37 \pm 1^{\circ} \mathrm{C}$ 'de $72-96$ saat inkube edildikten sonra üreyen en az $1 \mathrm{~mm}$ büyüklüğünde ve katalaz negatif olan koloniler sayılmıştır [34].

\subsection{Enterobacteriaceae grubu mikroorganizmaların belirlenmesi}

Violet Red Bile Glucose Agar (Oxoid CM0485)'a dökme plak yöntemiyle ekim yapılmış ve petrilerdeki besiyeri katılaştıktan sonra tekrar üzerlerine aynı besiyerinden $5 \mathrm{ml}$ kadar daha dökülerek petriler $30^{\circ} \mathrm{C}$ 'de 24 saat inkube edilmiştir. İnkubasyon sonrası yuvarlak ve mor renkli 1-2 mm çapındaki presipitasyon oluşturan tipik koloniler sayılmıştır [35].

\subsection{Pseudomonas spp.'nin belirlenmesi}

Pseudomonas CFC Selective Agar Supplement (Oxoid SR0103) ilave edilen Pseudomonas Agar Base (Oxoid CM0559)'e yayma plak yöntemiyle ekim yapılan petriler $25^{\circ} \mathrm{C}$ 'de 72 saat inkube edildikten sonra üreyen $1 \mathrm{~mm}$ çapından büyük ve oksidaz pozitif olan koloniler sayılmıştır [36]. 


\subsection{Sülfit indirgeyen anaerob mikroorganizmaların belirlenmesi}

Sulphite Polymxine Sulphadiasine Agar (Merck 110235)'a "roll tüp” tekniği ile ekim yapılmış, katılaşan besiyeri üzerine aynı besiyerinden yaklaşı $1 \mathrm{ml}$ daha ilave edilerek anaerob ortam sağlanmış ve $37^{\circ} \mathrm{C}$ ' de 24 saat inkubasyondan sonra siyah renkli kolonilerin oluşup oluşmadığına göre değerlendirme yapılmıştır [27].

\subsection{Maya-küf'lerin belirlenmesi}

Potato Dextrose Agar (Oxoid CM0139) eritilerek $121^{\circ} \mathrm{C}$ 'de $15 \mathrm{dk}$ sterilize edilmiş ve $50^{\circ} \mathrm{C}$ ' de steril $\% 10$ 'luk tartarik asitle pH's1 3.5 \pm 0.1 'e ayarlanmıştır. Dökme plak yöntemiyle ekim yapılan petriler 20$25^{\circ} \mathrm{C}$ 'de 5-7 gün inkube edilmiş ve üreyen koloniler sayılmıştır [37].

\subsection{3. $\mathrm{pH}$ ve su aktivitesi $\left(a_{\mathrm{w}}\right)$ değerlerinin belirlenmesi}

Numunelerde pH değeri [38] pH-metrede (Hanna ${ }^{\circledR}$ HI 221, Romanya) ve $\mathrm{a}_{\mathrm{w}}$ değeri [39] $\mathrm{a}_{\mathrm{w}}$-metrede (Novasina ${ }^{\circledR}$ MS 1 Set, İsviçre) belirlenmiştir.

\subsection{4. İstatistiksel analizler}

Analizler sonucunda elde edilen bulguların istatistiksel analizleri SPSS 22.0 programı kullanılarak yapılmıştır [40].

\section{Bulgular ve Tartışma}

İncelenen numunelerde tespit edilen toplam aeorob mezofilik mikroorganizmalar (TAMM), koliform grubu mikroorganizmalar, E. coli, S. aureus, koagulaz (+) S. aureus, Salmonella spp., laktobasiller, Enterobacteriaceae grubu mikroorganizmalar, Pseudomonas spp., sülfit indirgeyen anaerob mikroorganizmalar ile maya-küflere ait mikrobiyolojik analiz bulguları $\left(\log _{10} \mathrm{kob} / \mathrm{g}\right)$ Tablo 1'de, tespit edilen mikroorganizma gruplarının sıklık dağılımları $\left(\log _{10} \mathrm{kob} / \mathrm{g}\right)$ Tablo 2 'de ve fiziko-kimyasal analiz bulguları ise Tablo 3'de sunulmuştur.

Tatvan'da tüketime sunulan 50 adet tavuk döner numunesinde TAMM sayısı 3.30-7.42 $\log _{10}$ $\mathrm{kob} / \mathrm{g}$ arasında ve ortalama $4.86 \pm 0.94 \log _{10} \mathrm{kob} / \mathrm{g}$ olarak belirlenmiştir. Bu araştırmada tespit edilen ortalama TAMM sayısı, Yuksek ve ark. [41]'nın bildirdikleri ortalama $4.2 \times 10^{3} \mathrm{kob} / \mathrm{g}$ değerinden yüksek bulunmuştur. Pişmiş tavuk dönerlerde ortalama TAMM sayısını Ünver Alçay [26] $4.353 \pm 0.149 \log _{10}$ kob/g, Bostan ve ark. [21] $4.45 \pm 0.27 \log _{10} \mathrm{kob} / \mathrm{g}$, Kayisoglu ve ark. [19] $4.86 \log _{10} \mathrm{kob} / \mathrm{g}$, Öksüztepe ve Beyazgül [22] $5.11 \pm 0.31 \log _{10} \mathrm{kob} / \mathrm{g}$ ve Easa [42] $5.28 \log _{10} \mathrm{kob} / \mathrm{g}$ olarak bildirmişlerdir. Bu araştırmada numunelerde belirlenen TAMM sayıları ile diğer çalışmalarda tespit edilen sonuçlar arasındaki farklılıkların ana hammadde olarak kullanılan tavuk etleri ile üretimde kullanılan baharatların hijyenik kalitesinden, pişirme işlemlerinden, pişirme sırasındaki ısının yeterli derinliğe kadar ulaşamamasından ve pişirme sonrası oluşan kontaminasyonlardan kaynaklandığ1 düşünülmektedir. Seyitoğlu ve Ceylan [23] Erzurum'da inceledikleri 40 adet pişmiş tavuk döner örneğinde TAMM sayısının 3.36-4.61 $\log _{10}$ kob/g arasında belirlendiğini bidirmişlerdir. Vazgecer ve ark. [43] Ankara'da inceledikleri 72 adet pişmiş tavuk döner örneğinde TAMM sayısının $10^{2}-6.4 \times 10^{5} \mathrm{kob} / \mathrm{g}$ arasında belirlendiğini ve örneklerin yarısında bu sayının $10^{3}-10^{4} \mathrm{kob} / \mathrm{g}$ düzeyinde olduğunu bildirmişlerdir. Elazı ̆̆ da satışa sunulan 40 adet pişmiş tavuk dönerin \%12.5'inde [22] ve İstanbul'da incelenen 30 adet pişmiş tavuk dönerinin de \%30'unda [26] TAMM sayısının $5 \log _{10} \mathrm{kob} / \mathrm{g}$ seviyesinden yüksek olarak belirlendiği bildirilmiştir. Yine İstanbul'da incelenen 14 adet pişmiş kanatlı eti dönerinde de TAMM sayısının genel olarak $10^{3}$ $10^{4} \mathrm{kob} / \mathrm{g}$ düzeyinde olduğu ve bu sayının bazı örneklerde $10^{6} \mathrm{kob} / \mathrm{g}$ düzeylerine ulaştığı belirtilmiştir [21]. Ayaz ve ark. [44] Riyad'da (Suudi Arabistan) inceledikleri 30 adet pişmiş tavuk dönerinde (shawarma) TAMM sayısının $10^{2}-3 \times 10^{8} \mathrm{kob} / \mathrm{g}$ arasında belirlendiğini ve bunların \%83'ünde bu sayının $1.1 \times 10^{3}-10^{6} \mathrm{kob} / \mathrm{g}$ arasında olduğunu belirtmişlerdir. Pişmiş tavuk dönerler üzerine yapılan çalışmaların bazılarında ve bu araştırmada TAMM sayısının çok yüksek seviyelerde bile tespit edildiği görülmektedir. Stolle ve ark. [45] pişirilmiş dönerlerde tespit edilen TAMM sayısının bu ürünlerdeki mikrobiyolojik kalitenin belirlenmesindeki önemli kriterlerden biri olduğunu belirtmişlerdir. Dönerlerin 
üretiminde kullanılan etlerdeki mevcut mikrobiyal yük, hazırlama aşamalarında uygulanan işlemler, sunum sırasında kullanılan salata malzemeleri ve pişirilme işleminden sonra tüketime kadar geçen sürelerde oluşan kontaminasyonlar halk sağlığı açısından önemli riskler oluşturabilmektedir. $\mathrm{Bu}$ araştırmada incelenen numunelerde belirlenen TAMM sayısı ile koliform grubu mikroorganizmalar, $E$. coli ve Enterobacteriaceae' lar arasında istatistiksel olarak $\mathrm{p}<0.01$ düzeyinde önemli bir ilişki bulunması oluşabilecek riskleri gözler önüne sermektedir. Kanatlıların kesim aşamalarında hijyenik tedbirlere riayet edilmediğinde özellikle deride mikrobiyal yükün artması kaçınılmazdır $[9,12]$. Ancak, kanatlı eti dönerlerinin üretiminde kanatlıların derisinin de kullanılmasına izin verilmektedir [4,5]. Mikrobiyal yükün yoğun olabileceği derilerin kullanıldığı ürünler her ne kadar 1sıl işleme tabi tutulsalar dahi, bu deri parçalarının son ürünün mikrobiyolojik kalitesi üzerinde oluşturabileceği olumsuz etkilerin göz ardı edilmemesi gerekmektedir. Nitekim hem kırmızı etten hem de kanatlı etinden üretilen pişmiş dönerlerin mikrobiyolojik kalitelerinin incelendiği ve karşılaştırıldığı bazı çalışmalarda [7,19,21,22,25,41], kanatlı etinden üretilen dönerlerin daha yüksek seviyelerde mikroorganizma yüküne sahip oldukları bildirilmiştir.

Tablo 1. Pişirilmiş tavuk dönerlerin mikrobiyolojik analiz bulguları ( $\left.\log _{10} \mathrm{kob} / \mathrm{g}\right)(50 \mathrm{Adet})$

\begin{tabular}{|c|c|c|c|c|c|c|c|c|c|c|c|}
\hline & ТАМM & Koliform & E. coli ${ }^{*}$ & $\begin{array}{c}S . \\
\text { aureus* }\end{array}$ & $\begin{array}{c}\text { Koagulaz } \\
(+) S . \\
\text { aureus }\end{array}$ & $\begin{array}{c}\text { Salmonella } \\
\text { spp.* }\end{array}$ & Laktobasil & $\begin{array}{c}\text { Entero } \\
\text { bacteriaceae }\end{array}$ & $\begin{array}{c}\text { Pseudomonas } \\
\text { spp. }\end{array}$ & $\begin{array}{c}\text { Sülfit } \\
\text { ind. } \\
\text { aneorob }\end{array}$ & $\begin{array}{c}\text { Maya- } \\
\text { küf }\end{array}$ \\
\hline Min. & 3.30 & $<1.00$ & $<2.00$ & $<2.00$ & $<2.00$ & $\overline{T E}$ & $<1.00$ & $<1.00$ & $<2.00$ & $<1.00$ & $<1.00$ \\
\hline Maks. & 7.42 & 4.62 & 4.20 & 6.91 & 6.91 & $\mathrm{TE}$ & 7.44 & 4.74 & 4.15 & - & 4.41 \\
\hline Ort. \pm SS & $4.86 \pm 0.94$ & $2.34 \pm 1.17$ & $2.84 \pm 0.85$ & $4.00 \pm 1.04$ & $3.79 \pm 1.23$ & TE & $3.70 \pm 1.41$ & $2.64 \pm 1.04$ & $3.19 \pm 0.63$ & - & $2.39 \pm 1.02$ \\
\hline
\end{tabular}

*: Standartlarda limitleri verilen mikroorganizmalar; TE: Tespit edilmedi

Tablo 2. Pişirilmiş tavuk dönerlerdeki mikroorganizma gruplarının sıklık dağılımları $\left(\log _{10} \mathrm{kob} / \mathrm{g}\right)$

\begin{tabular}{|c|c|c|c|c|c|c|c|c|c|}
\hline & $\begin{array}{c}<1.0 \\
\mathrm{n}(\%)\end{array}$ & $\begin{array}{c}1.0-1.99 \\
\text { n }(\%)\end{array}$ & $\begin{array}{c}<2.0 \\
\mathrm{n}(\%)\end{array}$ & $\begin{array}{c}2.0-2.99 \\
\text { n }(\%)\end{array}$ & $\begin{array}{c}3.0-3.70 \\
\text { n }(\%)\end{array}$ & $\begin{array}{c}\text { 3.71-3.99 } \\
\text { n }(\%)\end{array}$ & $\begin{array}{c}\text { 4.0-4.99 } \\
\text { n }(\%)\end{array}$ & $\begin{array}{c}5.0-5.99 \\
\text { n }(\%)\end{array}$ & $\begin{array}{l}\geq 6.0 \\
\text { n (\%) }\end{array}$ \\
\hline TAMM & - & - & - & - & $3(\% 6)$ & $4(\% 8)$ & $22(\% 44)$ & $12(\% 24)$ & $9(\% 18)$ \\
\hline Koliformlar & $30(\% 60)$ & $9(\% 18)$ & - & $6(\% 12)$ & $1(\% 2)$ & $1(\% 2)$ & $3(\% 6)$ & - & - \\
\hline E. coli & - & - & $41(\% 82)$ & $5(\% 10)$ & $2(\% 4)$ & - & $2(\% 4)$ & - & - \\
\hline S. aureus & - & - & $29(\% 58)$ & $2(\% 4)$ & $8(\% 16)$ & $3(\% 6)$ & $5(\% 10)$ & $1(\% 2)$ & $2(\% 4)$ \\
\hline Koagulaz (+) S. aureus & - & - & $29(\% 58)$ & $5(\% 10)$ & $5(\% 10)$ & $3(\% 6)$ & $5(\% 10)$ & $1(\% 2)$ & $2(\% 4)$ \\
\hline Laktobasiller & $1(\% 2)$ & $1(\% 2)$ & - & $15(\% 30)$ & $11(\% 22)$ & $4(\% 8)$ & $6(\% 12)$ & $9(\% 18)$ & $3(\% 6)$ \\
\hline Enterobacteriaceae & $27(\% 54)$ & $7(\% 14)$ & - & $9(\% 18)$ & $2(\% 4)$ & - & $5(\% 10)$ & - & - \\
\hline Pseudomonas spp. & - & - & $34(\% 68)$ & $6(\% 12)$ & $6(\% 12)$ & $3(\% 6)$ & $1(\% 2)$ & - & - \\
\hline Sülf. ind. anaeroblar & $50(\% 100)$ & - & - & - & - & - & - & - & - \\
\hline Maya-küf & $6(\% 12)$ & $18(\% 36)$ & - & $14(\% 28)$ & $6(\% 12)$ & - & $6(\% 12)$ & - & - \\
\hline
\end{tabular}

Tablo 3. Pişirilmiş tavuk dönerlerin fiziko-kimyasal analiz bulguları (50 Adet)

\begin{tabular}{ccc}
\hline & pH değeri & $\mathbf{a}_{w}$ değeri \\
\hline Minimum & 5.69 & 0.960 \\
Maksimum & 6.40 & 0.999 \\
Ortalama \pm SS & $6.12 \pm 0.20$ & $0.985 \pm 0.01$ \\
\hline
\end{tabular}

$\mathrm{Bu}$ araştırmada incelenen pişmiş tavuk döner numunelerinin 30 (\%60)'unda koliform grubu mikroorganizmaya rastlanmamış olup $\left(<1.00 \log _{10} \mathrm{kob} / \mathrm{g}\right)$, bu mikroorganizma sayısı diğer numunelerde 1.00-4.62 $\log _{10} \mathrm{kob} / \mathrm{g}$ arasında ve ortalama $2.34 \pm 1.17 \log _{10} \mathrm{kob} / \mathrm{g}$ olarak belirlenmiştir. Pişmiş tavuk döner örneklerinde Kayisoglu ve ark. [19]'nın $2.42 \log _{10} \mathrm{kob} / \mathrm{g}$ ve Öksüztepe ve Beyazgül [22]'ün $2.13 \pm 0.21 \log _{10} \mathrm{kob} / \mathrm{g}$ olarak bildirdikleri ortalama koliform grubu mikroorganizma sayıları, bu araştırmada belirlenen ortalama değer ile benzerlik göstermektedir. Ayaz ve ark. [44], inceledikleri shawarma örneklerinin \%66'sinda koliform grubu mikroorganizmaya rastlanmadığını $(<10 \mathrm{kob} / \mathrm{g})$ ve diğer örneklerde $10^{1}-10^{5} \mathrm{kob} / \mathrm{g}$ arasında belirlendiğini bildirmişlerdir. Vazgecer ve ark. [43] da 
inceledikleri pişmiş tavuk dönerlerin \%39'unda bu grup mikroorganizmaların $10^{2} \mathrm{kob} / \mathrm{g}$ seviyesinin üzerinde tespit edildiğini ifade etmişlerdir. Seyitoğlu ve Ceylan [23] inceledikleri pişmiş tavuk dönerlerde koliform grubu mikroorganizma sayısının $<1-3.23 \log _{10} \mathrm{kob} / \mathrm{g}$ arasında belirlendiğini ve örneklerin \%72.50'sinde bu mikroorganizma sayısının $100 \mathrm{kob} / \mathrm{g}$ 'dan az olduğunu bildirmişlerdir. Pişirilmiş gıdalarda koliform grubu mikroorganizmaların belirlenmesi, yetersiz 1 sıl işlem uygulamalarından veya sonraki aşamalardaki kontaminasyonlardan kaynaklanmaktadır [9, 46]. Öksüztepe ve Beyazgül [22] Elazığ'da satışa sunulan pişmiş tavuk döner örneklerinin \%75'inde koliform grubu mikroorganizma tespit edilmesinin, hijyen yetersizliğinden ve tavuk derisinin üretimde kullanılmış olmasından kaynaklanabileceğini belirtmişlerdir. Bu araştırmada da yetersiz pişirme işlemlerinin, işletmelerde hijyen bilgisi eksik veya sağlıksız olan personel çalıştırılmasının ve yeterince hijyenik olmayan alet-ekipmanın kullanılmasının incelenen pişmiş dönerlerde koliform grubu mikroorganizmaların tespit edilmesindeki etkili faktörler olabileceği düşünülmektedir.

Yapılan mikrobiyolojik analizler sonucunda incelenen tavuk döner numunelerinin \%82'sinde E. coli' ye rastlanmamış olup ( $\left.<2.00 \log _{10} \mathrm{kob} / \mathrm{g}\right)$, bu mikroorganizma sayıs1 $9(\% 18)$ numunede 2.00 $4.20 \log _{10} \mathrm{kob} / \mathrm{g}$ arasında ve ortalama $2.84 \pm 0.85 \log _{10} \mathrm{kob} / \mathrm{g}$ olarak belirlenmiştir. Bu araştırmada incelenen numunelerin çoğunda $E$. coli tespit edilmemesi, inceledikleri pişmiş tavuk dönerlerin \%61'inde [43], \%64.29'unda [21] ve \%90'inda [26] E. coli'ye rastlamadıklarını bildiren araştırmaciların bulguları ile benzerlik göstermektedir. Et ürünlerinde ana kontaminasyon kaynakları başta hammadde olarak kullanılan et olmak üzere et işleme üniteleridir. Buralarda kesim, parçalama ve üretim işlemleri sırasında et ve et ürünleri çeşitli patojen ve patojen olmayan mikroorganizmalarla kontamine olabilmektedir [3]. Legnani ve ark. [47] İtalya'da 27 yemek fabrikasında yaptıkları bir araştırmada; ekipman ve çalışma yüzeylerinin \%10'unun kabul edilemeyecek oranda kontamine olduğunu, çiğ et ve et ürünlerinden oluşan gıda örneklerinden \%10.8'inin E. coli ile enfekte olduğunu bildirmişler, hijyenik kaliteyi iyileştirmek için personel eğitim programlarının ve HACCP uygulamalarının gerekli olduğunu belirtmişlerdir. E. coli'nin pişirilmiş ürünlerde bulunması fekal bir kontaminasyona işaret eder ve üretimde hijyen kriterlerine uyulmadığını gösterir [48]. TS 11859 Pişmemiş Döner Eti Standardı [49]'nda incelenen beş örneğin ikisinde bulunabilecek kabul edilebilir en fazla $E$. coli sayısının $1 \times 10^{3}$ $\mathrm{kob} / \mathrm{g}$ olabileceği belirtilmiştir. Buna göre incelenen 4 numunenin (\%8) bu mikroorganizma yönünden ilgili standartda belirtilen kritere uygun olmadığı görülmektedir (Tablo 2). Bu araştırmada numunelerde 3-4 $\log _{10} \mathrm{kob} / \mathrm{g}$ seviyelerinde $E$. coli belirlenmesinde, pişirme işlemlerinde yapılan hatalar ile üretim sırasında hijyenik tedbirlere riayet edilmemesi etkili olmuş olabilir. Nitekim, gıdalarda bulunan $E$. coli'nin, yapılacak standart pişirme uygulamaları ile aktivitelerini yitirebileceği ifade edilmektedir [9].

Doğada yaygın olarak bulunduğundan gıdalarda ve gıdaların işlenmesinde kullanılan ekipmanlarda da bulunabilen $S$. aureus, insan ve hayvanlarda çeşitli intoksikasyonlara ve buna bağl1 olarak da besin zehirlenmelerine neden olan patojen bir mikroorganizmadır [50]. Bu patojen mikroorganizma 1 sıl işlemler sırasında inaktif hale gelse de, salgıladığı enterotoksinler aktivitesini kaybetmez [51,52]. Toksin oluşmuş gıdanın alınması, ilk saatlerde karın ağrısı, kas ve karın krampları, bulant1, kusma ve ishal gibi şiddetli belirtilerle kendini gösteren bir toksikasyona neden olur [50,53]. Tatvan'da incelenen tavuk döner numunelerinin 29 (\%58)'unda S. aureus ve koagulaz (+) S. aureus'a rastlanmamış olup $\left(<2.00 \log _{10} \mathrm{kob} / \mathrm{g}\right)$, diğer numunelerde ortalama $S$. aureus sayıs1 $4.00 \pm 1.04 \log _{10}$ $\mathrm{kob} / \mathrm{g}$ ve koagulaz (+) S. aureus sayıs ise $3.79 \pm 1.23 \log _{10} \mathrm{kob} / \mathrm{g}$ olarak belirlenmiştir. Vazgecer ve ark. [43] inceledikleri pişmiş tavuk dönerlerin \%50'sinde stafilokokların $10^{2} \mathrm{kob} / \mathrm{g}$ 'dan yüksek bulunduğunu, ancak hiçbir örnekte koagulaz (+) S. aureus'a rastlanmadığını ifade etmişlerdir. Topçu [54] 25 adet pişmiş tavuk dönerin dördünde, Nur ve ark. [24] ise 50 adet tavuk dönerin ikisinde koagulaz (+) S. aureus belirlendiğini, ancak bu örneklerdeki seviyenin gida güvenilirliğini tehdit eden değerlerin altında bulunduğunu bildirmişlerdir. Bostan ve ark. [21] ile Öksüztepe ve Beyazgül [22] pişmiş tavuk dönerlerde S. aureus'a rastlanmamasının kullanılan hammaddelerden özellikle et ve baharatlarla ilişkilendirilebileceğini ifade etmişlerdir. Todd ve ark. [8] pişirilmiş dönerlerin bekletilmesi ile ilgili olarak yaptıkları çalışmada, dönerin pişirildikten sonra 1sı kaynağının kapatılarak bekletilmesi durumunda $S$. aureus sayısının $10^{4} \mathrm{kob} / \mathrm{g}$ '1 geçmediğini bildirmişlerdir. Bostan ve ark. [21] deneysel olarak yaptıkları çalışmada, ısıl işlem görmüş dönerlerin 6 saat oda sıcaklığında bekletildiğinde $S$. aureus sayısında bir artış görülmediğini, ancak pişirilmiş dönerlerin 18 saat oda sıcaklığında bekletildiğinde ise bu sayıda önemli bir artış olduğunu belirtmişler, ayrıca gün içinde tüketilemeyen dönerlerin şişte takılı bekletilerek ertesi gün tüketime sunulmasının halk sağlığ1 açısından risk oluşturabileceğini vurgulamışlardır. TS 11859 Pişmemiş Döner Eti Standardı [49]'nda incelenen beş 
örneğin ikisinde bulunabilecek kabul edilebilir en fazla $S$. aureus sayısının $5 \times 10^{3} \mathrm{kob} / \mathrm{g}\left(3.70 \log _{10}\right.$ $\mathrm{kob} / \mathrm{g}$ ) olabileceği belirtilmiştir. Buna göre incelenen 11 numunenin (\%22) bu mikroorganizma yönünden ilgili standartda belirtilen kritere uygun olmadığı görülmektedir (Tablo 2). Bu sonucun ortaya çıkmasında işletmelerde görev alan personellerin hijyen kurallarına uymaması etkili olmuş olabilir. Bu araştırmada tespit edilen TAMM sayısı ile $S$. aureus ve koagulaz (+) S. aureus arasında önemli bir ilişkinin $(\mathrm{p}<0.05)$ olması bu düşünceyi destekler mahiyettedir. $S$. aureus'un pişirilmiş ürünlerdeki varlığ 1 , yetersiz ısıtma işlemleri ile sonradan oluşan kontaminasyonlardan kaynaklanmaktadır [50,53]. Mikroorganizmaların inaktivasyonu için gıdalara uygulanan ısıl işlemin etkinliği önemlidir. Ancak yetersiz yapılan ısıl işlemler sonrasında gıdalarda mikroorganizmaların canlı kalabileceği unutulmamalı ayrıca pişirme sonrasında oluşabilecek kontaminasyonların önlenmesi için de gerekli hijyenik tedbirler alınmalıdır. Genel olarak el hijyenine dikkat eden sağlıklı ve eğitimli personelle birlikte hijyen kurallarına uyularak yapılacak üretim sayesinde olası gıda zehirlenmelerinin önüne geçilebilecektir.

$\mathrm{Bu}$ araştırmada incelenen pişmiş tavuk döner numunelerinin hiçbirinde Salmonella spp. tespit edilmemiştir (Tablo 1). Bu sonuç inceledikleri örneklerde Salmonella spp. izole edilmediğini bildiren araştırmacıların $[6,25,43,45]$ bulguları ile benzerdir. Pişmiş kanatlı eti dönerleri üzerine yapılan bazı çalışmalarda da \%3.33 [26], \%5.55 [55], \%14 [24] ve \%80 [19] gibi farklı oranlarda Salmonella spp. tespit edildiği bildirilmiştir. Türk Gıda Kodeksi Mikrobiyolojik Kriterler Yönetmeliği [56]'nde $1 s 1$ işlem görmüş dönerlerde ve TS 11859 Pişmemiş Döner Eti Standard1 [49]'nda Salmonella spp. bulunmasına izin verilmemektedir. Bu araştırmada Tatvan'da tüketime sunulan tavuk dönerlerin hiçbirinde Salmonella spp.'nin bulunmaması, incelenen numunelerin bu mikroorganizma açısından ilgili standartlara uygun olduğunun görülmesi açısından önemli ve tüketicilerde risk oluşturmaması yönünden de sevindirici bir sonuç olarak değerlendirilmiştir. Salmonella spp. 1 sıl işleme duyarlıdır ve $60^{\circ} \mathrm{C}$ 'de birkaç dakikada canlılığını yitirir [51]. Et içeriği fazla olan gıdalar mikroorganizmaların üremesi için uygun ortamlar olduğundan ve yetersiz şekilde yapılan 1sıl işlemler sonucunda da canlı kalabilen patojen mikroorganizmalar gıda zehirlenmelerine neden olabildiğinden dolayı, pişirme işlemleri etkili isıda yapılmalı ve üretimde hijyen kurallarına özen gösterilerek elde edilen ürünlerin mikrobiyolojik kalitesinin iyi olması sağlanmalıdır.

Isıl işlem görmüş tavuk dönerlerde laktobasillerin sayısı $<1.00-7.44 \log _{10} \mathrm{kob} / \mathrm{g}$ arasında ve ortalama $3.70 \pm 1.41 \log _{10} \mathrm{kob} / \mathrm{g}$ olarak belirlenmiştir. Bu araştırmada laktobasiller yönünden elde edilen bulgular, incelen pişmiş tavuk dönerlerinde laktobasillerin $10-10^{5} \mathrm{kob} / \mathrm{g}$ arası ve ortalama $3.38 \times 10^{3}$ $\mathrm{kob} / \mathrm{g}$ [7] ve Laktobacillus-Leuconostoc-Pediococcus'ların 1.89-5.76 $\log _{10} \mathrm{kob} / \mathrm{g}$ aras1 ve ortalama $3.64 \pm 0.43 \log _{10} \mathrm{kob} / \mathrm{g}$ [22] olarak belirlendiği bildirilen araştırmaların ortalama bulguları ile benzerdir. $\mathrm{Bu}$ araştırmada belirlenen TAMM sayısı ile laktobasiller arasında istatistiksel olarak önemli bir ilişki $(\mathrm{p}<0.01)$ bulunmuştur. İncelenen numunelerde dominant florayı oluşturan bu mikroorganizmalar arasındaki önemli ilişki, hiyyenik kalitenin çok iyi olmadığını göstermektedir.

İncelenen pişmiş tavuk döner numunelerinde Enterobacteriaceae sayıs $1<1.00-4.74 \log _{10} \mathrm{kob} / \mathrm{g}$ arasında ve ortalama $2.64 \pm 1.04 \log _{10} \mathrm{kob} / \mathrm{g}$ olarak belirlenmiştir. Pişirilmiş olarak tüketime sunulan tavuk dönerler üzerine yapılan bazı çalışmalarda da Enterobacteriaceae'ların varlığı farklı seviyelerde tespit edilmiştir. Öksüztepe ve Beyazgül [22] inceledikleri örneklerde Enterobacteriaceae sayısının $<1.00-4.89 \log _{10} \mathrm{kob} / \mathrm{g}$ arasında ve ortalama $4.03 \pm 0.19 \log _{10} \mathrm{kob} / \mathrm{g}$ olarak belirlendiğini, ayrıca örneklerin \%42.5'inde bu mikroorganizmanın tespit edilebilir seviyenin $\left(<1.0 \log _{10} \mathrm{kob} / \mathrm{g}\right)$ altında ve $\% 10$ 'unda da $4.0 \log _{10} \mathrm{kob} / \mathrm{g}$ '1n üstünde olduğunu bildirmişlerdir. Ünver Alçay [26] pişmiş tavuk dönerlerin \%50'sinde Enterobacteriaceae tespit edilmediğini $(<10 \mathrm{kob} / \mathrm{g})$ ve bu mikroorganizma sayısının ortalama $1.902 \pm 0.276 \mathrm{kob} / \mathrm{g}$ olarak belirlendiğini belirtmiştir. Seyitoğlu ve Ceylan [23] inceledikleri tavuk dönerlerde Enterobacteriaceae sayısının $<1-3.09 \log _{10} \mathrm{kob} / \mathrm{g}$ arasında belirlendiğini ve örneklerin \%75'inde bu mikroorganizma sayısının $100 \mathrm{kob} / \mathrm{g}$ ' dan az olduğunu bildirmişlerdir. Bostan ve ark. [21] 14 pişmiş kanatlı eti dönerinin 5'inde Enterobacteriaceae'ların tespit edilmediğini $(<10$ $\log _{10} \mathrm{kob} / \mathrm{g}$ ), 6'sinda $10^{2}-10^{3} \mathrm{kob} / \mathrm{g}$ seviyesinde ve 1 'inde de $10^{4} \mathrm{kob} / \mathrm{g}$ seviyesinde belirlendiğini bildirmişlerdir. Araştırmacılar Enterobacteriaceae'ların $10^{4} \mathrm{kob} / \mathrm{g}$ seviyesinde bulunmasının, döner işletmelerindeki üretim, pişirme ve servis aşamalarındaki hijyen standartları ve gıda güvenliği uygulamalarındaki farklılıklara işaret ettiğini ifade etmişlerdir. İncelenen ürünlerde toplam mikroorganizma sayısının tespit edilmesi genel olarak gıdaların mikrobiyolojik kalitesi hakkında bir fikir verse de, diğer indikatör ve patojen mikroorganizmaların da varlığının belirlenmesi önemlidir. Yapılacak çalışmalarda genellikle çevrede yaygın olarak bulunan ve canlıların bağırsak içeriğinde yaşayan Enterobacteriaceae'ların tespit edilmesi, ürünlerin işlenmesi ve servisi sırasında hijyen kriterlerine ne 
kadar dikkat edildiğini ortaya koyacaktır. Ayrıca, 1sıl işleme tabi tutulan et ürünlerinde Enterobacteriaceae'ların canlı kalması 1 sıl işlemlerin yetersiz yapıldığına işaret etmektedir [51]. Bu araştırmada da Enterobacteriaceae sayısının incelenen numunelerin ikisinde $3 \log _{10} \mathrm{kob} / \mathrm{g}$ ve beşinde 4 $\log _{10} \mathrm{kob} / \mathrm{g}$ seviyelerinde tespit edilmesi fekal bir kontaminasyon varlığını, uygulanan pişirme işlemlerinin etkin olmadığını veya üretim sırasında hijyen/sanitasyon kurallarına yeterince uyulmadığını göstermektedir. Bu mikroorganizma grubu ile TAMM, koliformlar, E. coli, S. aureus ve koagulaz (+) $S$. aureus arasında da istatistiksel olarak önemli bir ilişki $(\mathrm{p}<0.01)$ bulunması bunu destekler mahiyettedir. Doğru ve etkin bir şekilde yapılacak pişirme işlemleri ile üretimde görev alan personellere verilecek hijyen eğitimleri sayesinde, üretim/servis aşamalarında alınacak hijyenik önlemlerin artması ve son ürünün mikrobiyolojik yükünün azalması sağlanabilecektir.

Tatvan'da 1sıl işlem görmüş tavuk döner numunelerinde Pseudomonas spp. sayı1 $<2.00-4.15$ $\log _{10} \mathrm{kob} / \mathrm{g}$ arasında ve ortalama $3.19 \pm 0.63 \log _{10} \mathrm{kob} / \mathrm{g}$ olarak belirlenmiştir. Easa [42] El Qassium (Suudi Arabistan)'da satışa sunulan salatalı pişmiş tavuk dönerlerin (shawarma) hiçbirinde Pseudomonas'ların tespit edilmediğini bildirirken, Acar [7] İstanbul'da incelediği 30 adet pişmiş tavuk döner örneğinin 19'unda bu mikroorganizmaların $10-10^{5} \mathrm{kob} / \mathrm{g}$ arasında ve ortalama $1.68 \times 10^{3} \mathrm{kob} / \mathrm{g}$ olarak belirlendiğini bildirmiştir. Kaliteli hammadde kullanılmadan, tekniğine uygun olarak hazırlanmadan ve servis sırasında hijyenik şartlara uyulmadan satışa sunulan dönerler patojen mikroorganizmalar yönünden ciddi sağlık problemlerine yol açabilirler. Ayrıca dönerlerin ateşten ayrılarak tekrar tekrar 1sıtılması mikroorganizma gelişiminin artmasına neden olur [6, 57], bu ürünlerin genellikle kontrolsüz bir şekilde ve hijyen bilgisinden yoksun kişiler tarafindan üretilmesi de olası riskleri arttırır. Diğer çalışmaların bulgularına benzer şekilde bu araştırmada da incelenen numunelerin \%68'inde Pseudomonas spp. tespit edilmemiştir. Ancak, bu mikroorganizmalar ile koliformlar, $S$. aureus, koagulaz (+) S. aureus ve Enterobacteriaceae arasinda $\mathrm{p}<0.01$ ve E. coli arasinda $\mathrm{p}<0.05$ düzeylerinde istatistiksel yönden önemli bir ilişki olması, ayrıca Pseudomonas spp.'nin bazı numunelerde 3-4 $\log _{10} \mathrm{kob} / \mathrm{g}$ seviyelerinde belirlenmesi ilgili ürünlerin halk sağlığı açısından potansiyel bir risk oluşturduğunu göstermektedir.

Termofilik sporlu anaerob mikroorganizmalar genellikle kullanılan hammaddeler ile ilişkilidir ve yetersiz yapılan pişirme işlemleriyle inaktif olmazlar [46]. İnceledikleri pişmiş tavuk döner örneklerinde Vazgecer ve ark. [43] sülfit indirgeyen anaeroblara (\%7) rastlandığını, Kayisoglu ve ark. [19] da Clostridium perfringens (\%60) tespit edildiğini bildirmişlerdir. Bostan ve ark. [21] ile Öksüztepe ve Beyazgül [22] ise inceledikleri örneklerde sülfit indirgeyen anaerobların belirlenmediğini bildirmişler, kullanılan hammaddelerin özellikle et ve baharatların kaliteleri ile elde edilen bu sonucun bağlantılı olabileceğini ifade etmişlerdir. Benzer bir şekilde bu araştırmada da incelenen pişmiş tavuk dönerlerin hiçbirinde bu mikroorganizmalara rastlanmaması (Tablo 1) gıda güvenliği ve halk sağlığı açısından önemlidir.

Tatvan'da pişirilmiş olarak tüketime sunulan tavuk dönerlerde $2.39 \pm 1.02 \log _{10} \mathrm{kob} / \mathrm{g}$ olarak belirlenen ortalama maya-küf sayısı, farklı çalışmalarda ortalama $3.53 \log _{10} \mathrm{kob} / \mathrm{g}$ [19] ve $4.05 \pm 0.19$ $\log _{10} \mathrm{kob} / \mathrm{g}$ [22] olarak bildirilen değerlerden düşük bulunmuştur. Ayrıca, bu araştırmada incelenen numunelerin $\% 12$ 'sinde maya-küf sayısı $4 \log _{10} \mathrm{kob} / \mathrm{g}$ seviyesinde bulunmuş, Öksüztepe ve Beyazgül [22] de aynı seviyeye inceledikleri örneklerin \%12.5'inde rastlandığını bildirmişlerdir. Bu durum, araştırmacıların da benzer şekilde ifade ettikleri gibi bazı işletmelerde hijyen kurallarına yeterince uyulmadığını düşündürmektedir.

Fiziko-kimyasal özellikler yönünden Tatvan'da tüketime sunulan pişirilmiş tavuk döner numunelerinde $\mathrm{pH}$ değeri 5.69-6.40 arasında ve ortalama 6.12 $\pm 0.20, \mathrm{a}_{\mathrm{w}}$ değeri ise 0.960-0.999 arasında ve ortalama $0.985 \pm 0.01$ olarak belirlenmiştir (Tablo 3). Bu araştırmada belirlenen ortalama $\mathrm{pH}$ değeri pişmiş tavuk dönerler üzerine yapılan araştırmalarda $6.03 \pm 0.20$ [43] ve 6.07 [19] olarak bildirilen ortalama $\mathrm{pH}$ değerlerine benzer, 6.24 [23] olarak bildirilen değerden düşük bulunmuştur. Et ve ürünleri besin içeriklerinin zenginliği ve su aktivitesi ile $\mathrm{pH}$ değerlerinin uygunluğundan dolayı mikroorganizmaların faaliyetleri açısından uygun ortam oluştururlar [3, 9]. Ancak, 1sıl işlem uygulanmış etlerde $a_{w}$ değerleri düşer ve mikroorganizmaların üremesi için gerekli olan oksijen miktarı azalır. İncelenen bazı numunelerde mikroorganizma sayıları ile $\mathrm{a}_{\mathrm{w}}$ değerlerinin yüksek seviyelerde belirlenmiş olmas1, istatistiksel yönden de maya-küf sayısı ile $\mathrm{pH}(\mathrm{p}<0.01)$ ve $\mathrm{a}_{\mathrm{w}}(\mathrm{p}<0.05)$ değerleri arasında önemli düzeylerde ilişkilerin belirlenmesi bazı işletmelerde uygulanan pişirme işlemlerinin etkin ve yeterli şekillerde yapılmadığını düşündürmektedir. 


\section{Sonuç ve Öneriler}

Bitlis ilinin ekonomisi büyük oranda tarıma dayalı olmakla birlikte tarım sektörü içerisinde ağırlıklı kısmı canlı hayvan yetiştiriciliği oluşturmaktadır. Bölgede hayvancılığın yaygın olmasına ve yöresel tercihlere bağlı olarak et ve et ürünleri tüketimi fazladır. Ancak özellikle kırmızı et fiyatlarında meydana gelen artışa bağlı olarak, ülke genelinde olduğu gibi bu bölgede de et tüketiminde kanatlı etine doğru bir yönelme olduğu gözlenmektedir. Bölgede tüketilen kanatlı etlerinin temin edildiği merkezlerin büyük ölçüde bölgeye uzak olmaları ile taşıma ve depolama aşamalarında yapılan yanlış uygulamalar nedeniyle bu ürünlerin kontamine olma ihtimalleri artmaktadır. Bunun için kanatlıların kesimi, işlenmesi, depolanması, nakliyesi ve satışına kadar geçen bütün aşamalarda soğuk zincir korunmalı ve uygun olmayan ortamlarda yapılan tüm faaliyetler önlenmelidir.

Sonuç olarak; bu araştırma Bitlis iline bağlı ve İpek Yolu üzerinde önemli ticaret merkezlerinden biri olan Tatvan'daki gıda satış yerlerinde tüketime sunulan tavuk dönerlerde hijyen indikatörü mikroorganizmalar ile bazı önemli gıda patojenlerinin varlığının belirlenmesi açısından önem taşımaktadır. Bu araştırmada incelenen pişmiş tavuk döner numunelerinde Salmonella spp. ve sülfit indirgeyen anaeroblar tespit edilmemiştir. Ancak, koliform grubu mikroorganizmalar, E. coli, S. aureus, koagulaz (+) S. aureus, Enterobacteriaceae ve Pseudomonas spp. gibi hijyen indikatörü ve patojen mikroorganizmaların belirlenmesi bu ürünlerin halk sağlığı açısından potansiyel bir risk oluşturabileceğini göstermektedir. Isıl işlem görmüş tavuk dönerlerde bu mikroorganizmaların varlığı genel olarak; üretimde kullanılan hammade ve diğer katkı maddelerinin ilk mikrobiyal yüklerinin yoğun olmasından, pişirme sırasındaki ısının yeterli derinliğe kadar ulaşamamasından, sektörde hijyen kurallarından yoksun kişilerin görev almasından, ürünlerin servis edilmesi ve muhafazası aşamalarında oluşan sekonder kontaminasyonlardan kaynaklanmaktadır. İncelenen pişmiş tavuk dönerlerin mikrobiyolojik kalitesinin genel olarak iyi olmadığının tespit edilmesi; üretim ve tüketim aşamalarında alınacak hijyenik tedbirlerin ne kadar önemli olduğunu, işletmelerde gıda güvenliği yönetim sistemlerinin eksiksiz bir şekilde uygulanması gerektiğini ve ilgili kurumlarca daha sık aralıklarla hijyen denetimlerinin yapılması gerekliliğini göstermektedir.

Döner üretiminde kullanılan hammaddelerin özellikleri, ürüne lezzet vermek veya marinasyon amacıyla kullanılan yardımcı maddelerin mikrobiyal yükü, pişirme teknikleri, genellikle servisin yoğun olduğu öğlen saatlerinde yapılan yetersiz pişirme veya yüzeyden içe doğru pişmemiş kısımların aceleyle kalın bir şekilde alınması, görevli personellerin kişisel hijyenlerine dikkat etmemeleri veya genel hijyen kurallarına uymamaları ve servis sırasında oluşan kontaminasyonlar 1sıl işlem görmüş tavuk dönerlerin mikrobiyolojik kalitesini olumsuz yönde etkileyen önemli faktörlerdir. Bu olumsuzlukların ortadan kaldırılmasının yanında, gıda güvenliği yönetim sistemlerinin titizlikle hayata geçirilmesi de halk sağlığının korunması açısından oldukça gerekli uygulamalardır. Dönerlerin üretiminin yapıldığı mekanlar kontrol edilebilir bir şekilde havalandırılmalı, havalandırma sistemleri sık sık temizlenmeli ve sokağa açık bir şekilde pişirme/servis işlemleri yapılmamalıdır. Pişirme sırasında yeterli ısıl işlem uygulanmalı, pişmemiş kısımların alınmasından kaçınılmalı, kesilmiş dönerler bekletilmeden servis edilmeli ve kesinlikle ertesi gün satışa sunulmamalıdır.

Elde edilen bulgular ışı̆̆ında, üreticilerin ve işletmelerde görev alan personellerin hijyenik üretim, HACCP ve GMP uygulamaları, çapraz kontaminasyonları önleme, soğuk zincirin önemi, personel hijyeni ve sanitasyon kurallarına dikkat edilmesi gibi konularda bilinçlendirilmesi önemlidir. Aynı zamanda, nüfus yoğunluğu ve canlı ekonomisiyle Doğu Anadolu Bölgesi'nin önemli yerleşim yerlerinden biri olan Tatvan'da tüketime sunulan gıdaların mikrobiyolojik kalitesini belirlemek üzere yapılacak çalışmalar arttırılmalı ve eğitim faaliyetlerine hız verilerek bilinçlendirme çalışmalarına katkı sunulmalıdır.

\section{Teșekkür}

$\mathrm{Bu}$ araştırmayı maddi yönden destekleyen Bitlis Eren Üniversitesi Bilimsel Araştırma Projeleri Koordinatörlüğü' ne teşekkür ederiz (Proje No: BEBAP 2018.10). Ayrıca, bugüne kadar besin hijyeni ile ilgili yapmış olduğu akademik çalışmalarla bilim dünyasına birçok eser bırakan ve bu projenin tamamlanmasına yaklaştığımız 7 Mayıs 2020 tarihinde geçirmiş olduğu beyin kanaması sonucu hayatını kaybederek aramızdan ayrılan yol arkadaşımız Prof. Dr. Özgür İşLEYİCI’ye sonsuz sevgi ve saygılarımızı sunar, camiamıza baş sağlığı dileriz. 


\section{Yazarların Katkısı}

Hakan SANCAK yayının tüm aşamalarda aktif görev almış olup, Özgür İŞLEYİCI, Kamil EKİCİ ve Dilara BAŞAT DERELİ numunelerin alınması, analizlerin yürütülmesi ve istatistiki verilerin değerlendirilmesinde, Emrullah SAĞUN ve Yakup Can SANCAK ise sonuçların ve istatistiki verilerin yorumlanması ile makalenin biçim ve içerik kontrollerinde katkı sağlamışlardır.

\section{Çıkar Çatışması Beyanı}

Yazarlar arasında herhangi bir çıkar çatışması bulunmamaktadır.

\section{Araştırma ve Yayın Etiği Beyanı}

Yapılan çalışmada, araştırma ve yayın etiğine uyulmuştur. Araştırma etik kurul izni gerektirmemektedir.

\section{Kaynaklar}

[1] Hui Y.H. 2007. Factors affecting food quality: A primer. In: Handbook of Meat, Poultry \& Seafood Quality, Edited by Nollet L.M.L., Blackwell Publishing, Iowa, USA, 3-6.

[2] Öztan A. 2011. Et Bilimi ve Teknolojisi. 8. Baskı, TMMOB Gıda Mühendisleri Odası Yayınları Kitaplar Serisi No: 1, Filiz Matbaacıllı Sanayii Tic. Ltd Şti, Cebeci, Ankara.

[3] Arslan A. 2013. Et Muayenesi ve Et Ürünleri Teknolojisi. 2. Baskı, Medipres Matbaacıllk Ltd Şti, Malatya.

[4] Anonim, 2019. Türk Gıda Kodeksi Et, Hazırlanmış Et Karışımları ve Et Ürünleri Tebliği. Tebliğ No: 2018/52, RG: 29.01.2019, 30670, Ankara.

[5] Anonim, 1995. Döner Yapım Kuralları-Pişmemiş. TS 11658, 12 Nisan 1995, Türk Standartları Enstitüsü, Ankara.

[6] Jöckel J., Stengel G. 1984. Döner kebab-untersuchung und beurteilung einer Türkischen spezialität. Fleischwirtschaft, 64: 527-540.

[7] Acar M.S. 1996. Kasaplık Hayvan Etleri ve Tavuk Etinden Yapılan Döner Kebapların Mikrobiyolojik Kalitesinin Karşılaştırmalı Araştırması. Doktora Tezi, İstanbul Üniversitesi, Sağlık Bilimleri Enstitüsü, İstanbul.

[8] Todd E.C.D., Szabo R., Sipiring F. 1986. Donairs (Gyros) - potential hazards and control. Journal of Food Protection, 49 (5): 369-377.

[9] Uğur M., Nazlı B., Bostan K. 2001. Gıda Hijyeni. Teknik Yayınevi, İstanbul, 1-274.

[10] Küpeli Gençer V., Kaya M. 2004. Yaprak dönerin mikrobiyolojik kalitesi ve kimyasal bileşimi. Türkish Journal of Veterinary and Animal Sciences, 28 (6): 1097-1103.

[11] Cebirbay M.A. 2007. Dönerlerde Satış Süresi Boyunca Mikrobiyolojik Kalitede Meydana Gelen Değişmelerin Araştırılması. Yüksek Lisans Tezi, Selçuk Üniversitesi, Sağlık Bilimleri Enstitüsü, Konya.

[12] Marriott N.G., Schilling M.W., Gravani R.B. 2018. Principles of Food Sanitation. $6^{\text {th }}$ Ed, Springer International Publishing AG, Cham, Switzerland, 1-437.

[13] Sancak Y.C., Boynukara B., Ağaoğlu S. 1993. Van'da tüketime sunulan kıymaların mikrobiyolojik kalitesi. Yüzüncü Yıl Üniversitesi Veteriner Fakültesi Dergisi, 4 (1-2): 73-86.

[14] Sağun E., Sancak Y.C., Ekici K., Durmaz H. 1996. Van'da tüketime sunulan piliç but ve göğüs etlerinin hijyenik kalitesi üzerine bir araştırma. Yüzüncü Yıl Üniversitesi Veteriner Fakültesi Dergisi, 7 (1-2): 62-66.

[15] Sancak Y.C., İşleyici Ö. 2006. Çiğ köftelerin mikrobiyolojik kalitesi üzerine bir araştırma. Yüzüncü Y1l Üniversitesi Veteriner Fakültesi Dergisi, 17 (1-2): 81-86.

[16] Sancak Y.C., İşleyici Ö., Sağun E. 2007. Van'da tüketime sunulan bazı et ürünlerinde Listeria monocytogenes varlığı. Yüzüncü Y1l Üniversitesi Veteriner Fakültesi Dergisi, 18 (1): 93-99.

[17] Atlan M., İşleyici Ö. 2012. Van İli'nde dondurulmuş olarak satışa sunulan bazı et ürünlerinin mikrobiyolojik kalitesi. Atatürk Üniversitesi Veteriner Bilimleri Dergisi, 7 (2): 93-103. 
[18] Altun S.K., Atasever M. 2018. Erzurum'da tüketime sunulan tavuk etlerinin bazı patojen bakteriler yönünden incelenmesi. Manas Journal of Agriculture Veterinary and Life Sciences, 8 (1): 36-50.

[19] Kayisoglu S., Yilmaz I., Demirci M., Yetim H. 2003. Chemical composition and microbiological quality of the doner kebabs sold in Tekirdag market. Food Control, 14: 469-474.

[20] Elmalı M., Ulukanlı Z., Tuzcu M., Yaman H., Cavlı P. 2005. Microbiological quality of beef doner kebabs in Turkey. Archiv für Lebensmittelhygiene, 56 (2): 32-34.

[21] Bostan K., Yılmaz F., Muratoğlu K., Aydın A. 2011. Pişmiş döner kebaplarda mikrobiyolojik kalite ve mikrobiyel gelişim üzerine bir araştırma. Kafkas Üniversitesi Veteriner Fakültesi Dergisi, 17 (5): 781-786.

[22] Öksüztepe G., Beyazgül P. 2014. Elazı '̆' da satılan pişmiş et ve tavuk dönerlerin mikrobiyolojik kalitesi. Fırat Üniversitesi Sağlık Bilimleri Veteriner Dergisi, 28 (2): 65-71.

[23] Seyitoğlu Ş., Ceylan Z.G. 2014. Erzurum piyasasında tüketime sunulan tavuk dönerde Campylobacter spp. varlı̆̆ının araştırılması. Atatürk Üniversitesi Veteriner Bilimleri Dergisi, 9 (2): 104-111.

[24] Nur G., Deveci H.A., Kırpık M.A., Nur Ö., Ayata E. 2016. Gıda güvenilirliği kriterlerine göre Hatay'da satılan tavuk dönerlerinde mikrobiyolojik kalite. Kafkas Üniversitesi Fen Bilimleri Enstitüsü Dergisi, 9 (2): 14-22.

[25] Kaya A., Özpınar H., Çakmak Sancar B. 2018. Investigation of microbiological quality of raw and cooked "doner kebab" consumed in Istanbul. Asian Journal of Agriculture and Food Sciences, 6 (2): 78-83.

[26] Ünver Alçay A. 2019. İstanbul'da satılan pişmiş tavuk dönerlerin mikrobiyolojik kalitesinin araştırılması. Türk Mikrobiyoloji Cemiyeti Dergisi, 49 (2): 74-85.

[27] Harrigan W.F. 1998. Laboratory Methods in Food Microbiology. $3^{\text {rd }}$ Ed, Academic Press Limited, London, UK, 1-532.

[28] Swanson K.M.J., Busta F.F., Peterson E.H., Johnson M.G. 1992. Colony count methods. In: Compendium of Methods fort the Microbiological Examination of Foods, Edited by Vanderzant C., Splittstoesser D.F., $3^{\text {rd }}$ Ed, American Public Health Association (APHA) Technical Committee on Microbiological Methods for Foods, Washington DC, USA, 75-95.

[29] Pichhardt K. 1998. Lebensmittel-mikrobiologie, Grundlagen für die Praxis. Vierte Auflage, Springer Verlag, Berlin, Deutschland, 361.

[30] Anonymous, 2001. Microbiology of Food and Animal Feeding Stuffs - Horizontal Method for the Enumeration of beta-glucuronidase-positive Escherichia coli. Part 2: Colony-count technique at 44 degrees $\mathrm{C}$ using 5-bromo-4-chloro-3-indoyl beta-D-glucuronide, International Organization for Standardization, ISO 16649-2, ISO TC 34/SC 9.

[31] Anonymous, 2006. The Oxoid Manual. Compiled by Bridson E.Y., $9^{\text {th }}$ Ed, Oxoid Ltd, Hampshire, UK, $1-615$.

[32] Ünlütürk A., Turantaş F. 2015. Gıdaların Mikrobiyolojik Analizi. 3. Bask1, Meta Basım Matbaac1lık Hizmetleri, Bornova, İzmir, 1-166.

[33] Flowers R.S., D’Aoust J.Y., Andrews W.H., Bailey J.S. 1992. Salmonella. In: Compendium of Methods for the Microbiological Examination of Foods, Edited by Vanderzant C., Splittstoesser D.F., $3^{\text {rd }}$ Ed, American Public Health Association (APHA) Technical Committee on Microbiological Methods for Foods, Washington DC, USA, 371-422.

[34] Vedamuthu E.R., Raccah M., Glatz B.A., Seitz E.W., Reddy M.S. 1992. Acid producing organisms. In: Compendium of Methods for the Microbiological Examination of Foods, Edited by Vanderzant C., Splittstoesser D.F., $3^{\text {rd }}$ Ed, American Public Health Association (APHA) Technical Committee on Microbiological Methods for Foods, Washington DC, USA, 225-238.

[35] Anonymous, 2004. Microbiology of Food and Animal Feeding Stuffs - Horizontal Methods for the Detection and Enumeration of Enterobacteriaceae. Part 2: Colony-count method, International Organization for Standardization, ISO 21528-2, ISO TC 34/SC 9.

[36] Anonymous, 1995. Meat and Meat Products - Enumeration of Pseudomonas spp. International Organization for Standardization, ISO 13720, ISO TC 34/SC 6.

[37] Koburger J.A., Marth E.H. 1984. Yeasts and molds. In: Compendium of Methods for the Microbiological Examination of Foods, Edited by Speck M.L., $2^{\text {nd }}$ Ed, American Public Health 
Association (APHA) Technical Committee on Microbiological Methods for Foods, Washington DC, USA, 197-201.

[38] Gökalp H.Y., Kaya M., Tülek Y., Zorba Ö. 2015. Et ve Ürünlerinde Kalite Kontrolü ve Laboratuvar Uygulama K1lavuzu. 6. Bask1, Atatürk Üniversitesi Ziraat Fakültesi Ofset Tesisi, Erzurum, 1-316.

[39] Rahman M.S., Sablani S.S. 2009. Water activity measurement methods of foods. In: Food Properties Handbook, Edited by Rahman M.S., $2^{\text {nd }}$ Ed, CRC Press Taylor \& Francis Group, Boca Raton, USA, 9-32.

[40] Anonymous, 2013. IBM SPSS Statistics for Windows, Version 22.0. IBM Corp, Armonk, New York, USA.

[41] Yuksek N., Evrensel S.S., Temellı S., Anar S., Sen M.K.C. 2009. A microbiological evaluation on the ready-to-eat red meat and chicken donair kebabs from a local catering company in Bursa. Journal of Biological \& Environmental Sciences, 3 (7): 7-10.

[42] Easa S.M.H. 2010. Microorganisms found in fast and traditional fast food. Journal of American Science, 6 (10): 515-531.

[43] Vazgecer B., Ulu H., Oztan A. 2004. Microbiological and chemical qualities of chicken döner kebab retailed on the Turkish restaurants. Food Control, 15 (4): 261-264.

[44] Ayaz M., Othman F.A., Bahareth T.O., Al-Sogair A.M., Sawaya W.N. 1985. Microbiological quality of shawarma in Saudi Arabia. Journal of Food Protection, 48 (9): 811-814.

[45] Stolle A., Eisgruber H., Kerschhofer D., Krauße G. 1993. Döner kebab untersuchungen zur verkehrsauffassung und microbiologisch-hygienischen beschaffenheit im raum München. Fleischwirtschaft, 73 (9): 938-948.

[46] Erol İ. 2007. Gıda Hijyeni ve Mikrobiyolojisi. Pozitif Matbaacılık, Ankara, 1-392.

[47] Legnani P., Leoni E., Bervegliegri M., Mirolo G., Alvaro N. 2004. Hygienic control of mass catering establishments, microbiological monitoring of food and equipment. Food Control, 15 (3): 205-211.

[48] Doyle M.P., Cliver D.O. 1990. E. coli. In: Foodborne Disease, Edited by Cliver D.O., Academic Press Inc, New York, USA, 209-215.

[49] Anonim. 2016. Döner Eti-Pişmemiş. TS 11859, 29 Nisan 2016, Türk Standartları Enstitüsü, Ankara.

[50] Peacock S. 2006. Staphylococcus aureus. In: Principles and Practice of Clinical Bacteriology, Edited by Gillespie S.H., Hawkey P.M., $2^{\text {nd }}$ Ed, John Wiley \& Sons Ltd, UK, 73-98.

[51] Quinn P.J., Markey B.K., Leonard F.C., FitzPatrick E.S., Fanning S., Hartigan P.J. 2011. Veterinary Microbiology and Microbial Disease. $2^{\text {nd }} E d$, W1ley-Blackwell, UK, 1-911.

[52] Buhunia A.K. 2018. Foodborne Microbial Pathogens-Mechanisms and Pathogenesis. $2^{\text {nd }}$ Ed, Springer, New York, USA, 1-365.

[53] Seo K.S., Bohach G.A. 2013. Staphylococcus aureus. In: Food Microbiology: Fundamentals and Frontiers, Edited by Doyle M.P., Buchanan R.L., $4^{\text {th }}$ Ed, American Society for Microbiology (ASM) Press, Washington DC, USA, 547-573.

[54] Topçu S. 2006. Ankara'da Satışa Sunulan Döner Kebap Çeşitlerinden Listeria monocytogenes, Staphylococcus aureus, Aeromonas hydrophila İzolasyonu ve Çeşitli Antibiyotiklere Direçlilikleri. Yüksek Lisans Tezi, Gazi Üniversitesi, Fen Bilimleri Enstitüsü, Ankara.

[55] Al-Shadefat B. 2011. Tüketim Sürecinde Döner Kebaplarda Salmonella spp. Varlığının Araştırılması. Doktora Tezi, Selçuk Üniversitesi, Sağlık Bilimleri Enstitüsü, Konya.

[56] Anonim. 2011. Türk Gida Kodeksi Mikrobiyolojik Kriterler Yönetmeliği. RG: 29.12.2011, 28157 (3. Mükerrer), Ankara.

[57] Bryan F.L., Standley S.R., Henderson W.C. 1980. Time-temperature conditions of Gyros. Journal of Food Protection, 43 (5): 346-353. 